\title{
Green synthesis of silver nanoparticles using
}

\section{Pimpinella anisum seeds: antimicrobial activity and cytotoxicity on human neonatal skin stromal cells and colon cancer cells}

\author{
This article was published in the following Dove Press journal: \\ International Journal of Nanomedicine \\ 6 September 2016 \\ Number of times this article has been viewed
}

\author{
Mohamad S AISalhi ${ }^{1,2}$ \\ Sandhanasamy Devanesan ${ }^{1,2}$ \\ Akram A Alfuraydi ${ }^{3}$ \\ Radhakrishnan Vishnubalaji ${ }^{4}$ \\ Murugan A Munusamy ${ }^{3}$ \\ Kadarkarai Murugan ${ }^{5}$ \\ Marcello Nicoletti ${ }^{6}$ \\ Giovanni Benelli ${ }^{7}$ \\ 'Research Chair in Laser Diagnosis \\ of Cancers, ${ }^{2}$ Department of Physics \\ and Astronomy, ${ }^{3}$ Department of \\ Botany and Microbiology, College of \\ Science, ${ }^{4}$ Stem Cell Unit, Department \\ of Anatomy, College of Medicine, \\ King Saud University, Riyadh, \\ Kingdom of Saudi Arabia; ${ }^{5}$ Division \\ of Entomology, Department of \\ Zoology, School of Life Sciences, \\ Bharathiar University, Coimbatore, \\ India; ${ }^{6}$ Department of Environmental \\ Biology, Sapienza University of Rome, \\ Rome, ${ }^{7}$ Department of Agriculture, \\ Food and Environment, University \\ of Pisa, Pisa, Italy
}

Background: The present study focused on a simple and eco-friendly method for the synthesis of silver nanoparticles (AgNPs) with multipurpose anticancer and antimicrobial activities.

Materials and methods: We studied a green synthesis route to produce AgNPs by using an aqueous extract of Pimpinella anisum seeds ( $3 \mathrm{mM})$. Their antimicrobial activity and cytotoxicity on human neonatal skin stromal cells (hSSCs) and colon cancer cells (HT115) were assessed. Results: A biophysical characterization of the synthesized AgNPs was realized: the morphology of AgNPs was determined by transmission electron microscopy, energy dispersive spectroscopy, $\mathrm{X}$-ray powder diffraction, and ultraviolet-vis absorption spectroscopy. Transmission electron microscopy showed spherical shapes of AgNPs of $P$. anisum seed extracts with a $3.2 \mathrm{~nm}$ minimum diameter and average diameter ranging from 3.2 to $16 \mathrm{~nm}$. X-ray powder diffraction highlighted the crystalline nature of the nanoparticles, ultraviolet-vis absorption spectroscopy was used to monitor their synthesis, and Fourier transform infrared spectroscopy showed the main reducing groups from the seed extract. Energy dispersive spectroscopy was used to confirm the presence of elemental silver. We evaluated the antimicrobial potential of green-synthesized AgNPs against five infectious bacteria: Staphylococcus pyogenes (29213), Acinetobacter baumannii (4436), Klebsiella pneumoniae (G455), Salmonella typhi, and Pseudomonas aeruginosa. In addition, we focused on the toxicological effects of AgNPs against hSSC cells and HT115 cells by using in vitro proliferation tests and cell viability assays. Among the different tested concentrations of nanoparticles, doses $<10 \mu \mathrm{g}$ showed few adverse effects on cell proliferation without variations in viability, whereas doses $>10 \mu \mathrm{g}$ led to increased cytotoxicity.

Conclusion: Overall, our results highlighted the capacity of P. anisum-synthesized AgNPs as novel and cheap bioreducing agents for eco-friendly nanosynthetical routes. The data confirm the multipurpose potential of plant-borne reducing and stabilizing agents in nanotechnology.

Keywords: antibacterial, biosafety, green nanotechnology, metal nanoparticles, Pimpinella anisum seeds, cancer

\section{Introduction}

Nowadays, nanotechnology offers a novel approach to natural source utilization in order to improve drug delivery and bioactivity. The optimization of nanotechnology products is a key step. The synthesis of nanoparticles is usually conducted using various physical and chemical methods, which often require high-energy inputs and/or the production of toxic chemicals. In recent years, researchers in the field have strongly focused on the synthesis of metal nanoparticles because of their potential applications
Correspondence: Mohamad S AISalhi Research Chair in Laser Diagnosis of Cancers, Building No 4: College of Science, King Saud University, Riyadh, I I45I, Kingdom of Saudi Arabia

Tel +966 | 4676220

Fax+966 I 4673656

Email malsalhy@gmail.com 
in the development of novel technologies. ${ }^{1}$ The increasing demand for nanomaterials in the field of medicine, catalysis, water treatment, and solar energy conversion should be supported by eco-friendly synthesis routes in order to reduce energy inputs and hazardous waste. ${ }^{2-4}$ Two main chemical and physical methods are used to synthesize nanoparticles, but they are often costly and potentially harmful to the social environment. ${ }^{5,6}$ In this scenario, plant extracts have been used as novel and cheap bioreducing agents to produce nanoparticles for a wide number of applied purposes. ${ }^{4}$

Silver nanoparticles (AgNPs) represent a potential therapeutic tool for treatment of many diseases and parasites because of their antiplasmodial, antibacterial, and antifungal activity. ${ }^{4-8,9}$ Therefore, the green synthesis of nanoparticles is a hot research area nowadays, allowing the biosynthesis of safe, effective, low cost, and eco-friendly drugs, often mediated by the utilization of natural plant products. ${ }^{4,10}$

Pimpinella anisum L. (Apiaceae), commonly known as anise, is a well-known culinary herb, utilized for preparation of famous liqueurs but also largely used for its medicinal properties. ${ }^{11,12}$ For the latter application, the seeds are mainly used. Anise is a perennial herbal plant and grows up to a height of $\sim 2$ feet. The seeds are characterized by a sweet and aromatic bouquet with a distinctive liquorice flavor. Anise is an excellent source of many essential vitamins in the B-complex, such as pyridoxine, niacin, riboflavin, and thiamin. Antimicrobial activity of aqueous and ethanol anise seed extracts has also been reported. ${ }^{13,14}$

In this research, we studied a green synthesis route to produce AgNPs at room temperature using P. anisum seeds. Furthermore, the antimicrobial activity of AgNPs was evaluated via testing with five bacterial pathogens. Lastly, the impact of green-fabricated AgNPs on the proliferation and cell viability of human neonatal skin stromal cells (hSSCs) and colon cancer cells (HT115) was assessed. The use of human specimens in current study was approved by the Institutional Review Board at King Saud University College of Medicine (10-2815-IRB).

\section{Materials and methods}

\section{Chemicals}

Dulbecco's Modified Eagle's Medium supplemented with D-glucose (4,500 mg/L), 4 mM L-glutamine, $110 \mathrm{mg} / \mathrm{L}$ sodium pyruvate, $10 \%$ fetal bovine serum, $1 \times$ penicillin-streptomycin, and nonessential amino acids was used, and all agents were purchased from Thermo Fisher Scientific (Waltham, MA, USA).

\section{Preparation of the seed extract}

Fresh, healthy $P$. anisum seeds were collected from AlUla village in the Madinah region in the Kingdom of Saudi Arabia and washed ten times repeatedly with double distilled water to remove any surface contamination. The washed seeds were dried for 2 days at room temperature and then ground into a fine powder. Then, $10 \mathrm{~g}$ of the powder was added to $250 \mathrm{~mL}$ of water and soaked for 24 hours. The soaked mixture was filtered using Whatman no 1 filter paper. The extracts, utilized as a stock solution, were stored at $4^{\circ} \mathrm{C}$ until the testing phase.

\section{Synthesis of AgNPs}

Stock solution $(2.5 \mathrm{~mL})$ added into $250 \mathrm{~mL}$ of a silver nitrate solution ( $3 \mathrm{mM}$ ) was prepared for the synthesis of AgNPs. The reaction mixture was left standing for 96 hours until the light yellow color solution converted into a brown color. The above process was carried out at room temperature. ${ }^{15}$ The particles were purified by centrifugation at $10,000 \mathrm{rpm}$ for 15 minutes to remove excess silver ions. The centrifugation process was repeated three times to remove all silver colloids with double distilled water.

\section{Ultraviolet-visible (UV-vis) spectroscopy}

The AgNP optical properties were studied using UV-vis spectroscopy (Perkin Elmer Inc., Waltham, MA, USA) with a $950 \lambda$ scanning range from 100 to $1,100 \mathrm{~nm}$. UV-vis spectra were recorded periodically until the light yellow color solution turned into a brown color (96 hours).

\section{Fourier transform infrared spectroscopy (FTIR)}

The reducing and stabilizing groups from anise seed extract were characterized by FTIR spectroscopy using a Shimadzu FT-IR Prestige 21 (Shimadzu Corporation, Kyoto, Japan).

\section{Transmission electron microscopy (TEM), energy dispersive spectroscopy (EDS), and X-ray powder diffraction (XRD)}

TEM analysis was performed using a JEOL JEM-1230 (JEOL, Tokyo, Japan) at an accelerating voltage of $100 \mathrm{kV}$. In addition, the JSM-6380 LA (JEOL) high contrast $30 \mathrm{kV}$ scanning electron microscope was utilized to record the morphology (operated at $10 \mathrm{kV}$ ) of samples. EDS was used to examine the formation of synthesized AgNPs using the Ultima IV XRD system scanning in 2 theta (degree).

\section{Bacterial suspension preparation}

Bacterial strains of Staphylococcus pyogenes (29213), Acinetobacter baumannii (4436), Klebsiella pneumoniae (G455), Salmonella typhi, and Pseudomonas aeruginosa were obtained from King Khalid Hospital, Riyadh, Kingdom of 
Saudi Arabia. All bacterial cells had been identified by standard biochemical tests according to the guidelines of the clinical and laboratory standards institute. ${ }^{16}$ All the identified cultures were transferred on nutrient agar medium and kept at $-20^{\circ} \mathrm{C}$ for further study. Each bacterium strain was inoculated into the sterile nutrient agar and incubated at $37^{\circ} \mathrm{C}$ for 24 hours. Fresh suspension (106 CFU/mL) was prepared by transfer of a loop of inoculum from 24 hourincubated culture into $5 \mathrm{~mL}$ of nutrient broth and exposed for 2 hours at $37^{\circ} \mathrm{C} .{ }^{17}$

\section{Antimicrobial assays}

Antimicrobial activity assays were carried out using the agar well-diffusion method. ${ }^{18}$ The sterile swab was moistened with the fresh bacterial suspension and spread on a solid sterile Muller Hinton agar plate. Five wells ( $5 \mathrm{~mm}$ diameter) were made on the agar plate using a cork borer. Different concentrations $(10,20,30,40$, and $50 \mu \mathrm{L})$ of the synthesized nanoparticles suspension were poured into each consecutive well. All plates were incubated at $37^{\circ} \mathrm{C}$ for 24 hours. A zone of inhibition was measured ( $\mathrm{mm}$ ) around each well in every incubated plate. For each experiment, three replicates were maintained. ${ }^{19}$

\section{Cytotoxicity assays}

The effect of $P$. anisum seed extract of synthesized AgNPs on cellular proliferation was evaluated using a bioreductive fluorometric assay (BUF012B; AbD Serotec, Langford Ln, Kidlington OX5 1GE, United Kingdom). Between 5,000 and 10,000 cells per well were plated and grown in complete cell culture media within ten replica in 96-well tissue culturetreated microtiter plates and incubated for 12-24 hours at $37^{\circ} \mathrm{C}$. Numbers of cells plated per well were dependent on the rate of growth of cell lines in the flask. Media were removed, and various concentrations of AgNPs diluted in complete culture media were added. Control wells consisted of media alone. Cell proliferation and viability were determined at 24 and 48 hours following the addition of AgNPs. At these times, $20 \mu \mathrm{L}$ of Alamar Blue was added to each well, and the plates were incubated at $37^{\circ} \mathrm{C}$ for 4 hours. After incubation, plates were read using a spectrophotometric microplate reader (Biotek Synergy 2; Biotek Instruments, Highland Park, Winooski, Vermont, NE, USA) and the relative fluorescence unit was recorded.

In order to determine whether exposure to AgNPs affects cell viability, cells were stained with dual fluorescent staining solutions $(1 \mu \mathrm{L})$ containing $100 \mu \mathrm{g} / \mathrm{mL}$ acridine orange (AO) and $100 \mu \mathrm{g} / \mathrm{mL}$ ethidium bromide (EB) (SigmaAldrich Co., St Louis, MO, USA). Cells were washed twice with phosphate-buffered saline and gently mixed with $\mathrm{AO} /$ EB (1:100) dye solution for 1 minute; later, the cells were observed and photographed under a Nikon Eclipse Ti fluorescence microscope. Cells cultured without AgNPs were considered the experiment control. AO/EB staining uses a combination of two dyes to visualize cells with aberrant chromatin organization. The differential uptake of $\mathrm{AO} / \mathrm{EB}$ allows for the identification of viable and nonviable cells. In particular, AO was used to visualize the number of cells that had undergone apoptosis.

\section{Statistical analysis}

Statistical analyses and graphing were performed using Microsoft Excel 2010 (Microsoft Corporation, Redmond, WA, USA) and GraphPad Prism 6.0 software (GraphPad, San Diego, CA, USA). $P$-values were calculated using a two-tailed $t$-test $(P<0.05)$.

\section{Results and discussion}

The results showed that our method allowed for cheap and reliable synthesis of AgNPs within 96 hours. No highly toxic chemicals or energy inputs were needed. AgNPs were synthesized from the aqueous anise seed extract, which acted as a capping and stabilizing agent. The reduction of silver ions into AgNPs was confirmed by the color change to reddish brown for 96 hours at room temperature (Figure 1A). In the meantime, the control yellowish extract showed no change in color (Figure 1B). The reaction exhibits excitation of surface plasmon vibrations in AgNPs. ${ }^{20,21}$

Figure 2 shows UV-vis spectra recorded at different time intervals from Figure $1 \mathrm{~A}$ at room temperature. There was a strong absorbance band peak at $442 \mathrm{~nm}$ in spectra recorded in time intervals at 96 to 196 hours. Previously, it was shown that AgNPs can be synthesized within 24 hours and in the presence of ammonia, which enhances the formation of a

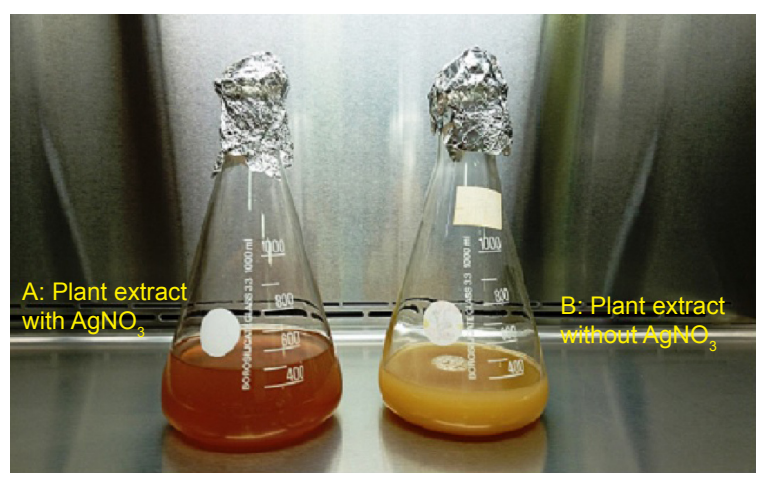

Figure I Green synthesis of silver nanoparticles using the aqueous extract of Pimpinella anisum seeds: (A) seed extract postreaction with $\mathrm{AgNO}_{3}$; (B) P. anisum seed extract alone. 


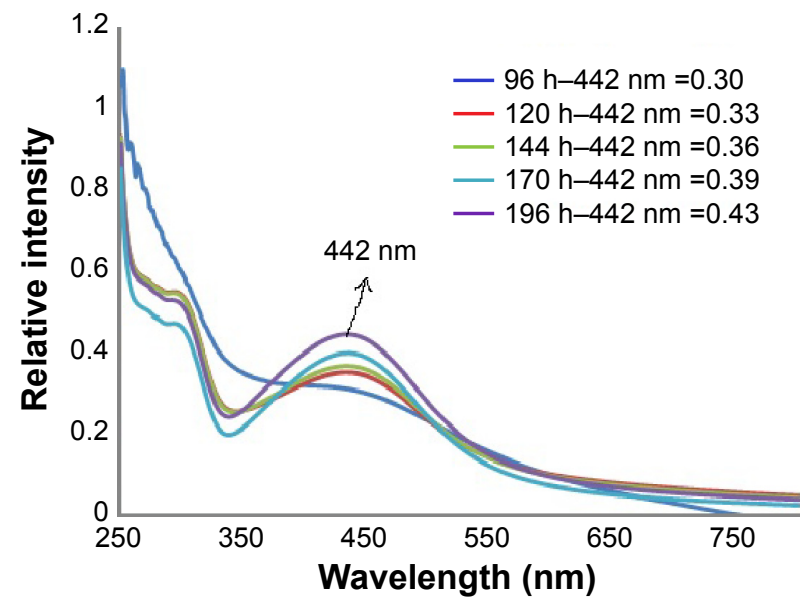

Figure 2 Pimpinella anisum-synthesized silver nanoparticles: UV-vis spectra recorded over different time intervals, until $196 \mathrm{~h}$.

Abbreviations: UV-vis, ultraviolet-visible; h, hours.

soluble silver complex. ${ }^{22,23}$ The spectra clearly showed that the concentration of relative intensity ratio was increased $0.30,0.33,0.36,0.39$, and 0.43 , respectively. This indicates the amount of $P$. anisum seed extract in the reaction medium that interacted with silver nitrate. Previous studies have shown that the spherical AgNPs contribute to the absorption bands at around $420-430 \mathrm{~nm} \cdot{ }^{24}$ Over time, the peak became sharper and the intensity increased due to the increasing of nanoparticles formed in accordance with the reduction of $\mathrm{Ag}$ ions present in the solution. ${ }^{25-27}$

FTIR spectroscopy is useful for identifying the reducing and stabilizing groups from the plant extract responsible for nanosynthesis. ${ }^{4,28}$ The FTIR spectrum showed five peaks at $3,287,2,925,1,642,1,300$, and $1,034 \mathrm{~nm}$ due to the $\mathrm{OH}$,
$\mathrm{CH}, \mathrm{COO}, \mathrm{C}=\mathrm{C}$, and $\mathrm{C}=\mathrm{O}$ groups, respectively (Figure 3). In addition, the spectrum showed the presence of active biomolecules in the plant seed extract of $P$. anisum, which may act as the main constituents leading to biosynthesis of AgNPs using seed extract of $P$. anisum.

Figure 4 shows the X-ray diffraction analysis of AgNPs synthesized from $P$. anisum seed aqueous extract. It indicated the four main characteristic peaks at 2 theta values of the $38^{\circ}$, $44^{\circ}, 65^{\circ}$, and $78^{\circ}$ family of parallel planes, highlighting the cubic structure of AgNPs, in agreement with other biosyntheses of AgNPs using eco-friendly green methods. ${ }^{4,29,30}$

Figure 5 reports the TEM results, confirming that the AgNPs were in the nano-range size. AgNPs were spherical in shape and had a minimum size of $3.2 \mathrm{~nm}$. The maximum size was around $16 \mathrm{~nm}$ with an average diameter of $8.3 \mathrm{~nm}$ after 96 hours of reaction at room temperature. ${ }^{20}$ In previous reports, the size of AgNPs produced using other aromatic herbs was $13.37 \mathrm{~nm}$ minimum (seed extract of Citrullus colocynthis). ${ }^{30}$

Figure 6 shows the EDS analysis, which recorded the elemental composition profile of the synthesized AgNPs. Major peaks assigned to Ag were observed, and the intense signal at $3 \mathrm{keV}$ strongly suggested that Ag was the major element used, whereas the other peaks could be assigned to carbon, oxygen, potassium, and hydrogen, which corresponded to the biomolecules capping the AgNPs. ${ }^{26,29}$

Figure 7 (1a, 2a, 3a, 4a, 5a) shows the antibacterial effects of various concentrations of $P$. anisum seed extract alone $(10,20,30,40$, and $50 \mu \mathrm{L})$. Figure 7 (1b, 2b, 3b, 4b, 5b) also shows the antibacterial effects of various concentrations of

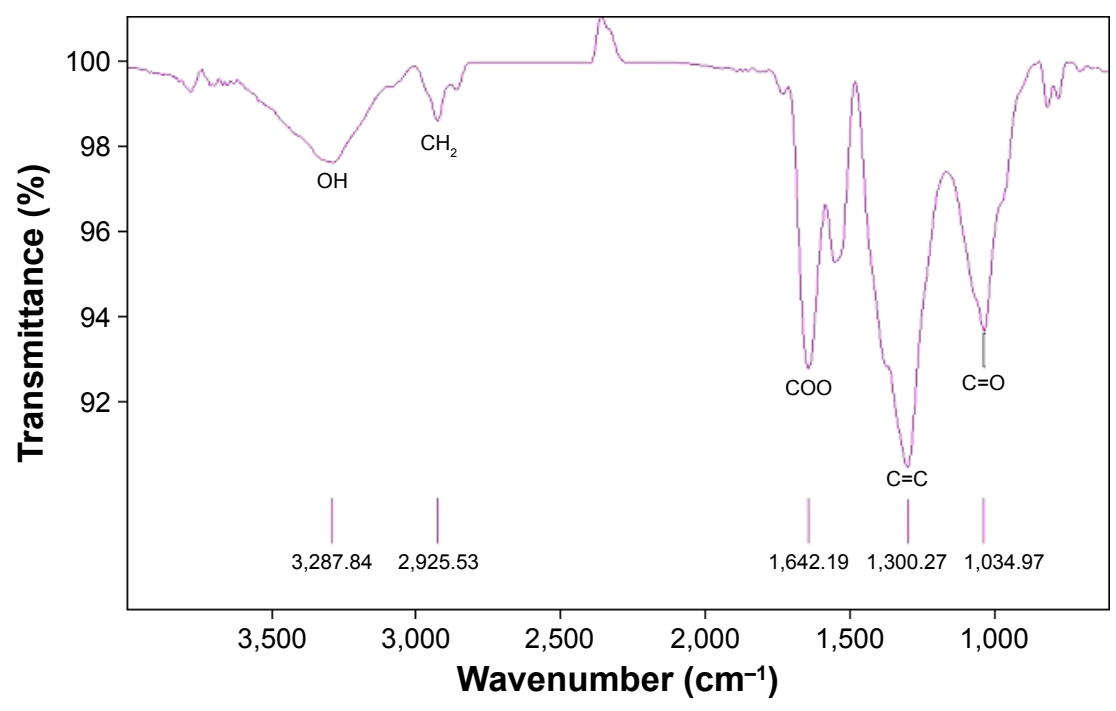

Figure 3 FTIR spectrum of dried powder of Pimpinella anisum-synthesized silver nanoparticles. Abbreviation: FTIR, Fourier transform infrared spectroscopy. 


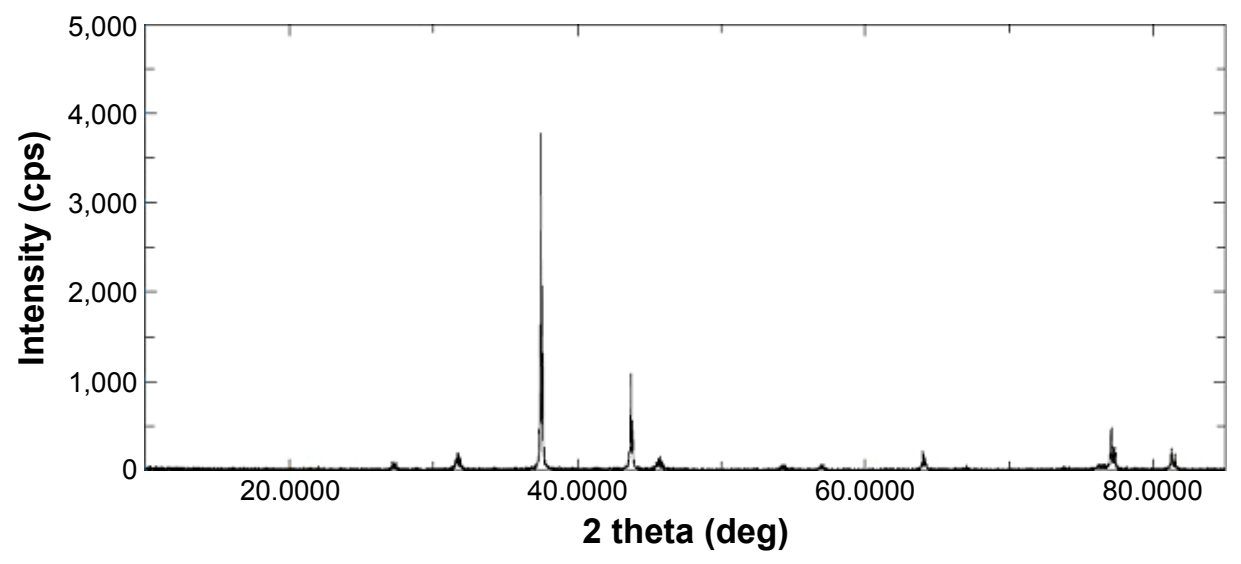

Figure 4 XRD confirmed the crystalline nature Pimpinella anisum-synthesized silver nanoparticles. Abbreviation: XRD, X-ray powder diffraction.

AgNPs against $S$. pyogenes (29213), A. baumannii (4436), K. pneumoniae (G455), S. typhi, and P. aeruginosa, studied using the diffusion method. AgNPs showed significant antibacterial activity against all tested pathogens. The inhibition zones were AgNP dose-dependent, and the maximum zone of inhibition was obtained at $50 \mu \mathrm{L}$ (Figure 6). The high antibacterial potential of our synthesized AgNPs may be related to their larger surface area, shape, and ultrafine structure, as highlighted by our TEM results. Indeed, the ultrafine size and larger surface area of the synthesized AgNPs help to deactivate cellular enzymes and damage the bacterial cell membrane because of positively charged $\mathrm{Ag}^{+}$ ions. ${ }^{27}$ This leads to enzymatic dysfunction ${ }^{29}$ and damage to proteins and $\mathrm{DNA}^{30}$ because of the release of reactive oxygen species by AgNPs, ending in cell death. In addition, it was reported that the spherical and hexagonal shapes of AgNPs are responsible for the inhibition of the Gram-negative bacterium Escherichia coli. ${ }^{25}$ However, the actual mechanism of action against the bacterial cell by the synthesized AgNPs

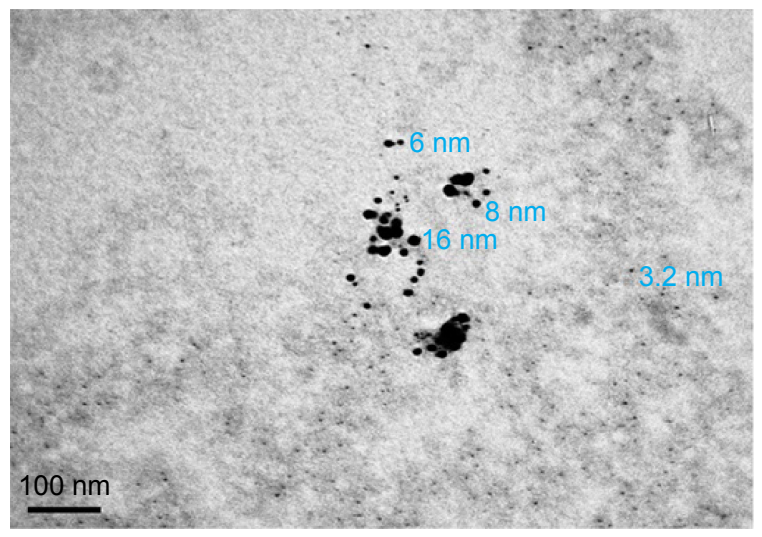

Figure 5 TEM of Pimpinella anisum-synthesized silver nanoparticles. Abbreviation: TEM, transmission electron microscopy. has not been fully determined. ${ }^{31}$ The chemical synthesis involves toxic solvents, high pressure, energy, and high temperature. On the other hand, microbial nanosynthesis is not feasible industrially because of the high cost of culture maintenance. In this scenario, green synthesis using aromatic plant extracts may be a better candidate for the synthesis of nanoparticles. ${ }^{15}$ In addition, the antimicrobial activity of AgNPs might be boosted because of the presence of plant extract secondary metabolites, such as polyphenols, flavonoids, and tannins. ${ }^{32}$

The Alamar Blue assay was used to measure cell proliferation and viability and is based on the reduction potential of metabolically active cells. Both cell types were exposed to AgNPs $(2-50 \mu \mathrm{g} / \mathrm{mL})$ for 24 hours. No significant signs of toxicity were observed at AgNPs concentrations up to $10 \mu \mathrm{g} / \mathrm{mL}$ (Figures 8 and 9), but some

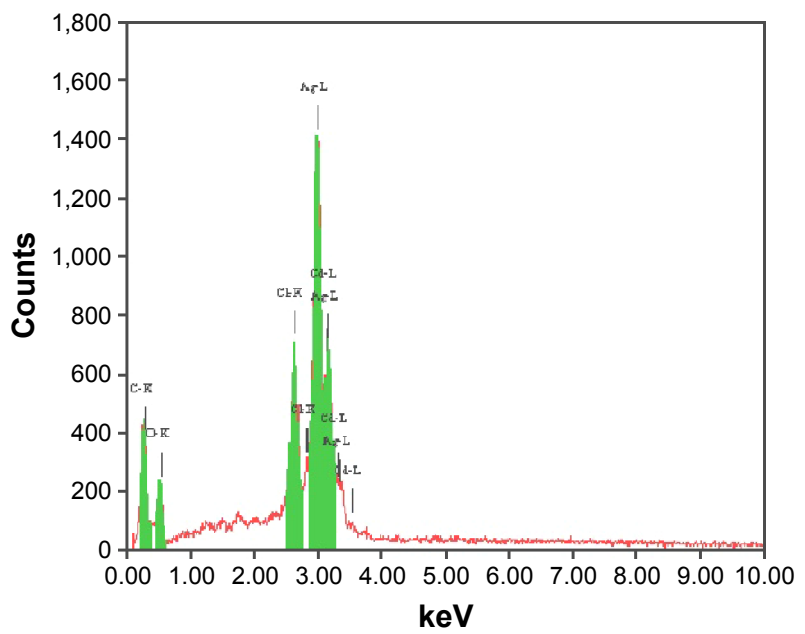

Figure 6 EDS showing the presence of Ag in Pimpinella anisum-synthesized silver nanoparticles.

Abbreviation: EDS, energy dispersive spectroscopy. 
A
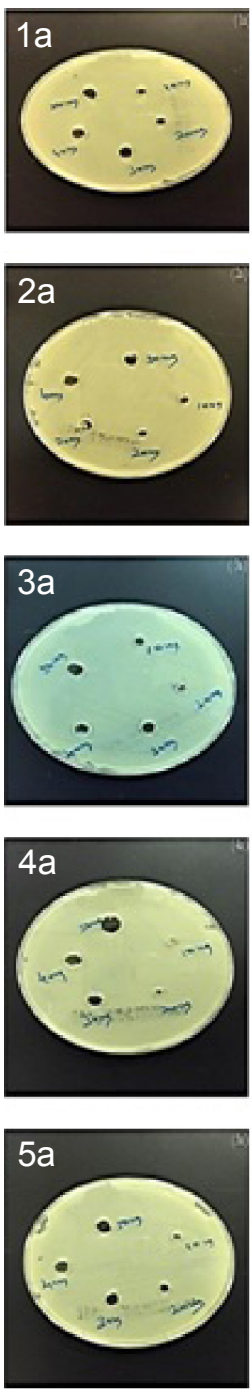
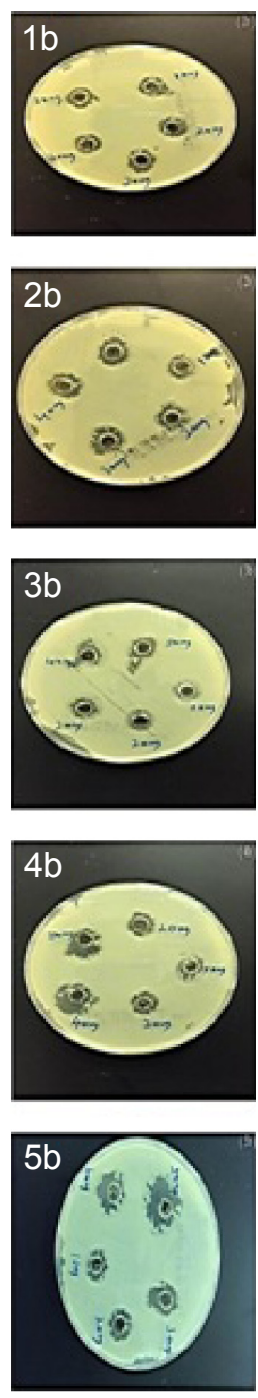

B
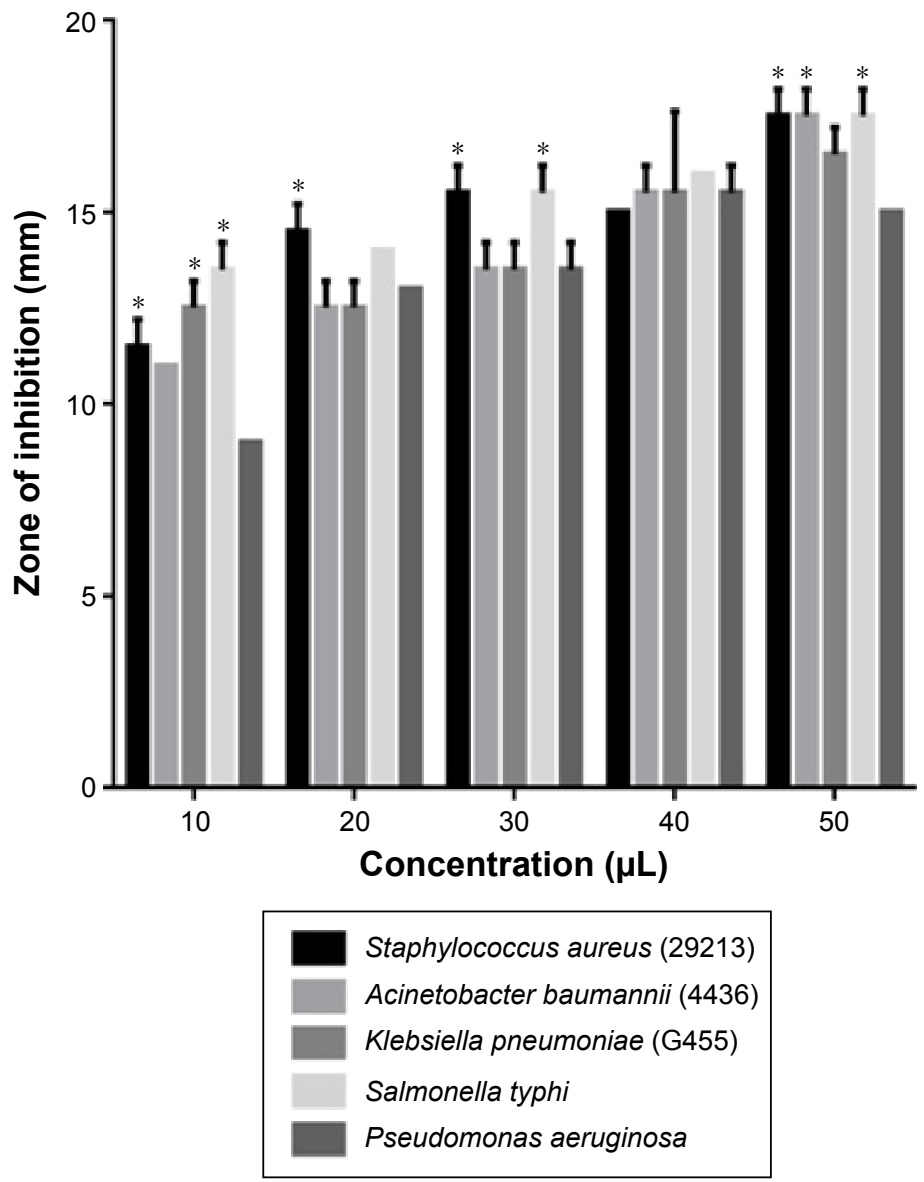

Figure 7 Antibacterial effect of Pimpinella anisum seed extract (A) ( $\mathrm{la}, 2 \mathrm{a}, 3 \mathrm{a}$, 4a, and 5a corresponding to $10 \mu \mathrm{L}, 20 \mu \mathrm{L}, 30 \mu \mathrm{L}, 40 \mu \mathrm{L}$, and $50 \mu \mathrm{L}$, respectively) and anisefabricated silver nanoparticles (Ib, $2 b, 3 b, 4 b$, and $5 b$ ). (B) Bar diagram representation of zone of inhibition, two-tailed $t$-test $($ data are presented as mean $\pm \mathrm{SE}$, $\mathrm{n}=5$ ). $* P<0.05$.

A
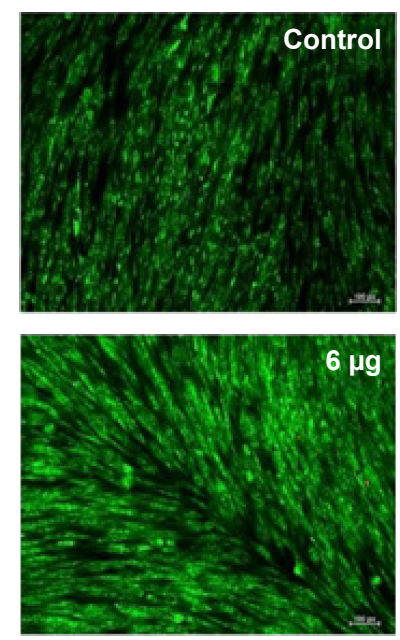

Cell viability assessment
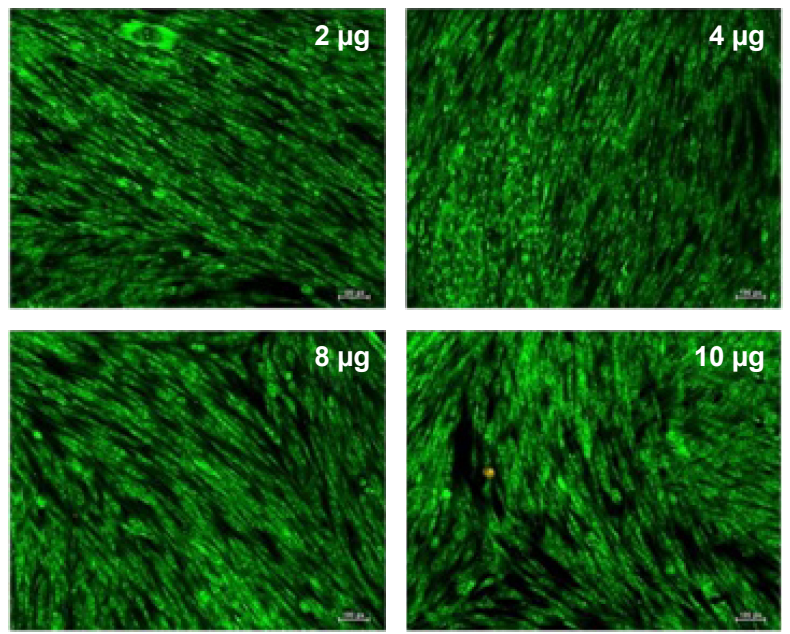


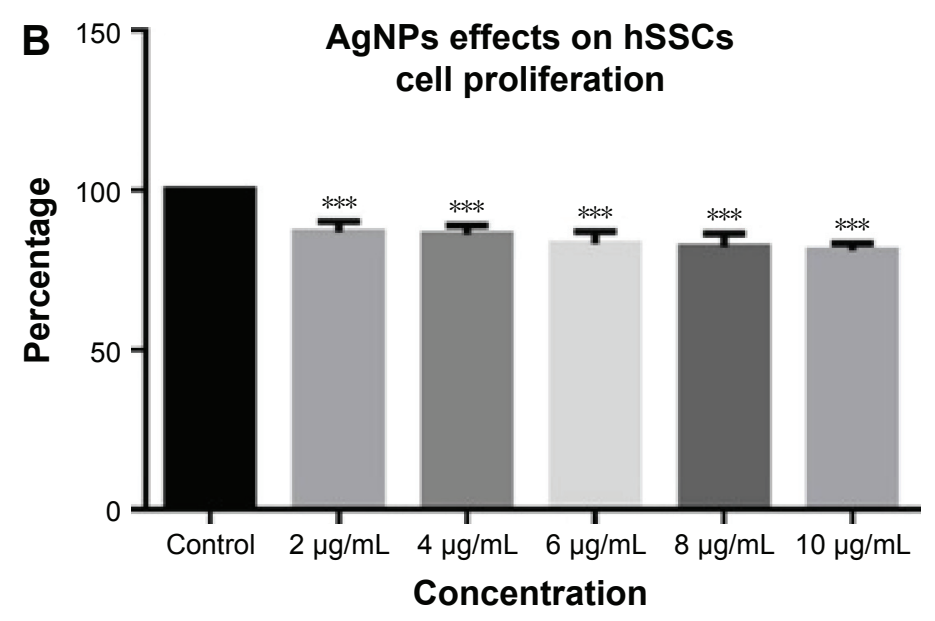

Figure 8 Cell viability $(\mathbf{A})$ and proliferation $(\mathbf{B})$ in hSSCs exposed to different doses of Pimpinella anisum-synthesized silver nanoparticles (AgNPs) (2-10 $\mu$ g/mL). Note: (A) Scale bars $=10 \mu \mathrm{m}$. (B) Alamar blue assay showing the proliferation (\%) decline in a dose dependent manner. Mean $\pm \mathrm{SE}, \mathrm{n}=10$. $* * *<0.0005$.

Abbreviation: hSSCs, human neonatal skin stromal cells.

reduction in proliferation was observed. Significant cell toxicity was observed at concentrations $>10 \mu \mathrm{g}(20,30$, 40 , and $50 \mu \mathrm{g} / \mathrm{mL}$ ) (Figures S1 and S2). The overall findings suggest that concentrations of AgNPs $>10 \mu \mathrm{g} / \mathrm{mL}$ are toxic to the cells, causing either apoptosis or necrosis. The viability was confirmed by AO/EB staining. No significant apoptosis was detected at concentrations $<10 \mu \mathrm{g} / \mathrm{mL}$ (Figures 8 and 9). At concentrations $>10 \mu \mathrm{g} / \mathrm{mL}$, necrotic cells increased in volume and dead orange-red fluorescence cells were observed. Interestingly, toxicity was higher in HT115 cancer cells in comparison to normal primary hSSCs, and this warrants further investigation (7A and B).

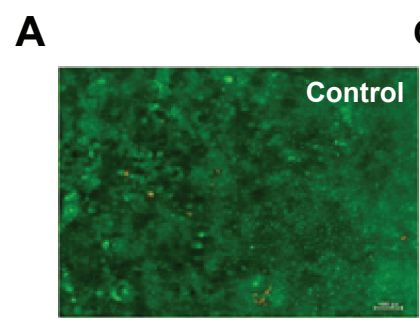

Cell viability assessment
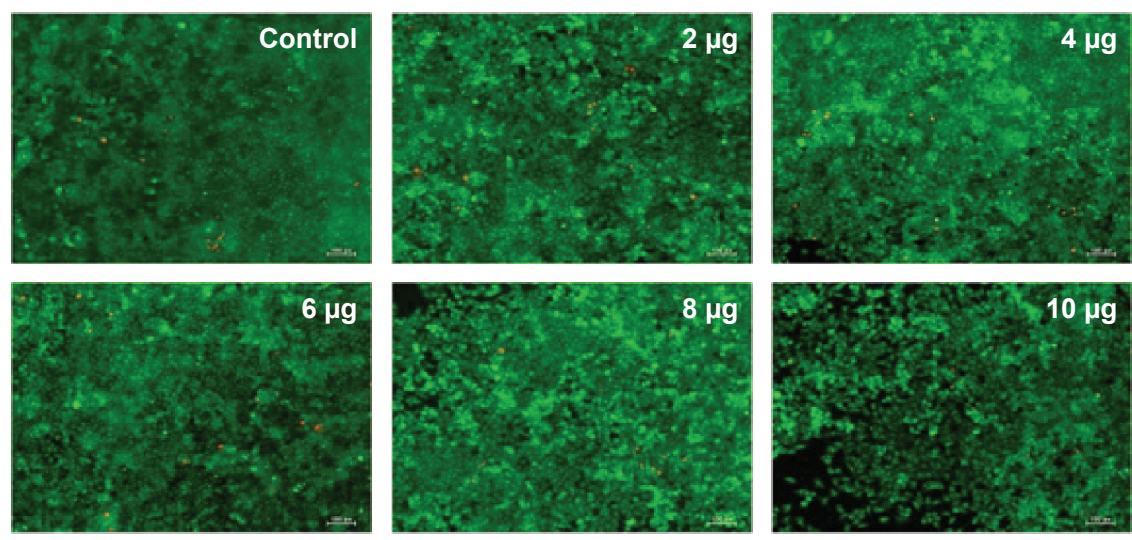

B

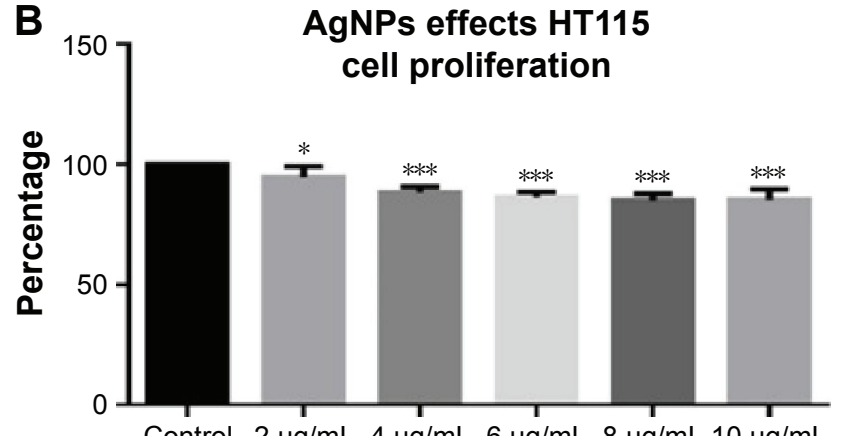

Control $2 \mu \mathrm{g} / \mathrm{mL} 4 \mu \mathrm{g} / \mathrm{mL} 6 \mu \mathrm{g} / \mathrm{mL} 8 \mu \mathrm{g} / \mathrm{mL} 10 \mu \mathrm{g} / \mathrm{mL}$

\section{Concentration}

Figure 9 Cell viability (A) and proliferation (B) in HTII 5 exposed to different doses of Pimpinella anisum-synthesized silver nanoparticles (AgNPs) (2-10 $\mu \mathrm{g} / \mathrm{mL})$. Notes: AgNPs effects on HTII 5 cell viability and proliferation, (A) Fluorescence images of hSSCs cells $( \pm \mathrm{AgNPs}$, exposure of different concentration [2-10 $\mu \mathrm{g} / \mathrm{mL}]$ ) stained with acridine orange/ethidium bromide to analyse the apoptosis and viability. Scale bars= $10 \mu \mathrm{m}$. (B) Alamar blue assay showing the proliferation (\%) decline in a dose dependent manner. Data are presented as mean $\pm \mathrm{SE}, \mathrm{n}=10$. $* P<0.05 ; * * * P<0.0005$.

Abbreviations: AgNPs, Silver nanoparticles; HTII5, Colon cancer cell line. 
The toxicity of different NPs was assessed in the mouse spermatogonial stem cell line. Among the various AgNPs sizes, $15 \mathrm{~nm}$ was the most toxic $(5-10 \mu \mathrm{g} / \mathrm{mL})$, resulting in drastically reduced mitochondrial function and increased membrane leakage. ${ }^{33}$ Furthermore, during the investigation of the size-dependent cellular interactions of AgNPs (Ag-15 nm, Ag-30 nm, and Ag-55 nm), the cell viability significantly decreased with increasing concentration (10-75 $\mu \mathrm{g} / \mathrm{mL}$ ) of Ag-15 and Ag-30 nm. In addition, the investigation showed more than tenfold levels of reactive oxygen species, observed in cells exposed to $50 \mu \mathrm{g} / \mathrm{mL}$ Ag-15 nm, and it was suggested that the toxicity might be exhibited via oxidative stress. ${ }^{34}$ Both chemically and biologically synthesized nanoparticles and their toxic effect value and percentage were measured. The green-synthesized AgNPs toxic effects were lower compared to chemically synthesized AgNPs (biologically synthesized AgNP cytotoxicity was $51.39 \%$ and cytotoxicity was over $85.45 \%$ for chemically synthesized AgNPs). ${ }^{35}$

\section{Conclusion}

In this study, a simple and cheap approach was attempted to fabricate green AgNPs using an aqueous solution of $P$. anisum seed extract. The nanoparticles were mostly spherical in shape with an average size of $8.3 \mathrm{~nm}$. The AgNPs biosynthesized from $P$. anisum also exhibit excellent antimicrobial activities in five different microorganisms. The AgNPs also showed cytotoxicity on hSSCs and HT115s. The green synthesis of AgNPs is an effective and eco-friendly process for producing nanodrugs for pharmacological applications.

\section{Acknowledgment}

This project was fully financially supported by King Saud University through Vice Deanship of Research Chairs. This synthesis method has won an US patent recently (US patent issued on September 29, 2015; Publication number US 9144544 B1).

\section{Author contributions}

MSA and SD designed the study. All authors contributed toward the experiments, data analysis, drafting and revising the paper and agree to be accountable for all aspects of the work.

\section{Disclosure}

The authors report no conflicts of interest in this work.

\section{References}

1. Prashant KJ, Xiaohua H, Ivan HS, Mostafa AS. Noble metals on the nanoscale: optical and photothermal properties and some applications in imaging, sensing, biology, and medicine. Acc Chem Res. 2008; 41(12):1578-1586.

2. Dahl JA, Maddux BL, Hutchison JE. Toward greener nanosynthesis. Chem Rev. 2007;107(6):2228-2269.

3. Raveendran P, Jie F, Scott LW. Completely "green" synthesis and stabilization of metal nanoparticles. J Am Chem Soc. 2003;125(46): 13940-13941.

4. Benelli G. Plant-mediated biosynthesis of nanoparticles as an emerging tool against mosquitoes of medical and veterinary importance: a review. Parasitol Res. 2016;115(1):23-34.

5. Makarov VV, Love AJ, Sinitsyna OV, et al. Green nanotechnologies: synthesis of metal nanoparticles using plants. Acta Nat. 2014;1(20): $35-43$.

6. Kaushik NT, Snehit SM, Rasesh YP. Biological synthesis of metallic nanoparticles. 2010;6(2):257-262.

7. Kim JS, Kuk E, Yu KN, et al. Antimicrobial effects of silver nanoparticles. Nanomedicine. 2007;3(1):95-101.

8. Asmaa AA, Dina R, El-Gowelli HM, Amal HK. Green synthesis of silver nanoparticles using cranberry powder aqueous extract: characterization and antimicrobial properties. Int J Nanomed. 2015;10: 7207-7221.

9. Rajeshkumar S, Malarkodi C. In-vitro antibacterial activity and mechanism of silver nanoparticles against foodborne pathogens. Bioinorg Chem Appl. 2014;2014(581890):1-10.

10. Roy N, Gaur A, Jain A, Bhattacharya S, Rani V. Green synthesis of silver nanoparticles: an approach to overcome toxicity. Environ Toxicol Pharmacol. 2013;36(3):807-812.

11. Pruthi JS. Spices and Condiments. 2nd ed. New Delhi: National Book Trust; 1976:1-21.

12. EMA/HMPC/321185/2012 Committee on Herbal Medicinal Products (HMPC). Community herbal monograph on Pimpinella anisum L., aetheroleum. London: European Medicines Agency. November 12, 2013.

13. Gülçın İ, Oktay M, Kıreçcı E, et al. Screening of antioxidant and antimicrobial activities of anise (Pimpinella anisum L.) seed extracts. Food Chem. 2003;83(3):371-382.

14. Akhtar A, Deshmukh AA, Bhonsle AV, Kshirsagar PM, Kolekar MA. In vitro antibacterial activity of Pimpinella anisum fruit extracts against some pathogenic bacteria. Vet World. 2008;1(9):272-274.

15. Anamika M, Sanjukta C, Rai PM, Wata G. Evidence based green synthesis of nanoparticles. Adv Mat Lett. 2012;3(6):519-525.

16. Matthew LF, Blake WB, Josh H, et al. Multicenter evaluation of the bruker MALDI biotyper CA system for the identification of clinical aerobic gram-negative bacterial isolates. PLoS One. 2015; 10(11): 0141350.

17. Girish HV, Satish S. Antibacterial activity of important medicinal plants on human pathogenic bacteria - a comparative analysis. World Appl Sci J. 2008;5(3):267-271.

18. Cruickshank R. Medical Microbiology: A Guide to Diagnosis and Control of Infection. 11th ed. Edinburgh and London: E\&S. Livingston Ltd; 1968:888.

19. Saraniya Devi J, Valentin Bhimba B. Silver nanoparticles: antibacterial activity against wound isolates $\&$ in vitro cytotoxic activity on human Caucasian colon adenocarcinoma. Asian Pac J Trop Dis. 2012; 2(S1):S87-S93.

20. Suman TY, Radhika Rajasree SR, Kanchana A, Elizabeth SB. Biosynthesis, characterization and cytotoxic effect of plant mediated silver nanoparticles using Morinda citrifolia root extract. Colloids Surf B Biointerfaces. 2013;106:74-78.

21. Gnanajobitha G, Paulkumar K, Vanaja M, et al. Phytosynthesis of silver nanoparticles by Cissus quadrangularis: influence of physicochemical parameters. J Nanostructure Chem. 2013;67:1-6.

22. Chandran SP, Chaudhary M, Pasricha R, Ahmad A, Sastry M. Synthesis of gold nanotriangles and silver nanoparticles using Aloe vera plant extract. Biotechnol Prog. 2006;22(2):577-583. 
23. Jancy ME, Inbathamizh L. Green synthesis and characterization of nano silver using leaf extract of Morinda pubescens. Asian J Pharm Clin Res. 2002;5(S1):159-162.

24. Seyed SM, Sattar G. Experimental study on effect of different parameters on size and shape of triangular silver nanoparticles prepared by a simple and rapid method in aqueous solution. Arabian J Chem. 2009; 2(1):47-53.

25. Naheed A, Seema S. Green synthesis of silver nanoparticles using extracts of Ananas comosus. Green Sustain Chem. 2012;2(4): 141-147.

26. Murugan K, Madhiyazhagan P, Dinesh D, et al. Rapid biosynthesis of silver nanoparticles using Crotalaria verrucosa leaves against the dengue vector Aedes aegypti: what happens around? An analysis of dragonfly predatory behavior after exposure at ultra-low doses. Nat Prod Res. 2016;30(7):826-833.

27. Harekrishna B, Dipak KB, Gobinda PS, Priyanka S, Santanu P, Ajay M. Green synthesis of silver nanoparticles using seed extract of Jatropha curcas. Colloids Surf A Physicochem Eng Asp. 2009;348(1-3): 212-216.

28. Smith PR, Holmes JD, Richardson DJ, Russell DA, Sodeau JR. Photophysical and photochemical characterization of bacterial semiconductor cadmium sulfide particles. J Chem Soc Faraday Trans. 1998; 94(9):1235-1241.

29. Arokiyaraj S, Arasu MV, Vincent S, et al. Rapid green synthesis of silver nanoparticles from Chrysanthemum indicum L. and its antibacterial and cytotoxic effects: an in vitro study. Int J Nanomedicine. 2014;9:379-388
30. Monalisha R, Swati SP, Nabin KD. Synthesis of silver nano particles from plant extract and its application in cancer treatment: a review. Int J Plant Animal Environ Sci. 2014;4(3):137-145.

31. Sukdeb P, Yu KT, Joon MS. Does the antibacterial activity of silver nanoparticles depend on the shape of the nanoparticle? A study of the gram-negative bacterium Escherichia coli. Appl Environ Microbiol. 2007;73(6):1712-1720.

32. Carlson C, Hussain SM, Schrand AM, et al. Unique cellular interaction of silver nanoparticles: size-dependent generation of reactive oxygen species. J Phys Chem B. 2008;112(43):13608-13619.

33. Aryou E, Mahdi K, Mohammad S, Sabihe SZ. Effect of nanocomposite packaging containing $\mathrm{Ag}$ and $\mathrm{ZnO}$ on inactivation of Lactobacillus plantarum in orange juice. Food Control. 2011;22(3-4):408-413.

34. Oliver G, Tünde VS, Priscilla SB, et al. Silver coordination polymers for prevention of implant infection: thiol interaction, impact on respiratory chain enzymes, and hydroxyl radical induction. Antimicrob Agents Chemother. 2010;54(10):4208-4218.

35. Pankaj KT, Shruti T, Charul V, Rajpal A. Estimation of toxic effects of chemically and biologically synthesized silver nanoparticles on human gut microflora containing Bacillus subtilis. J Toxicol Environ Health Sci. 2013;5(9):172-177. 


\section{Supplementary materials}

A
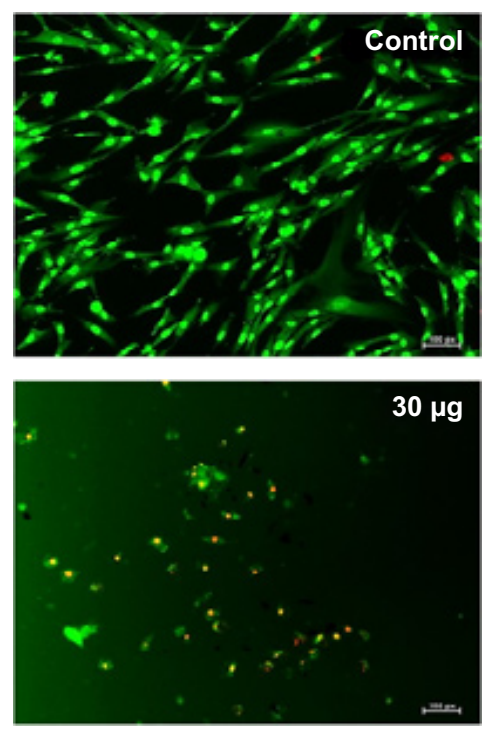

B

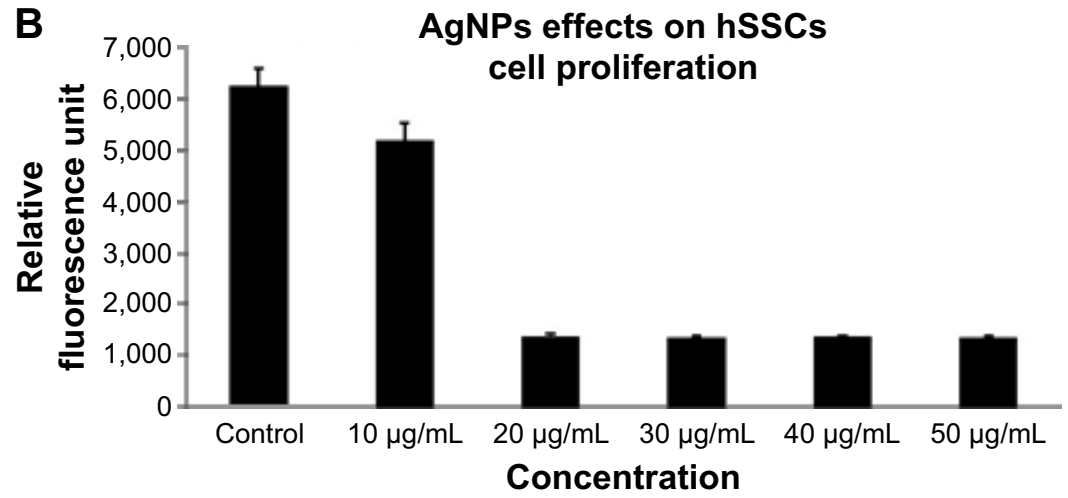

Cell viability assessment
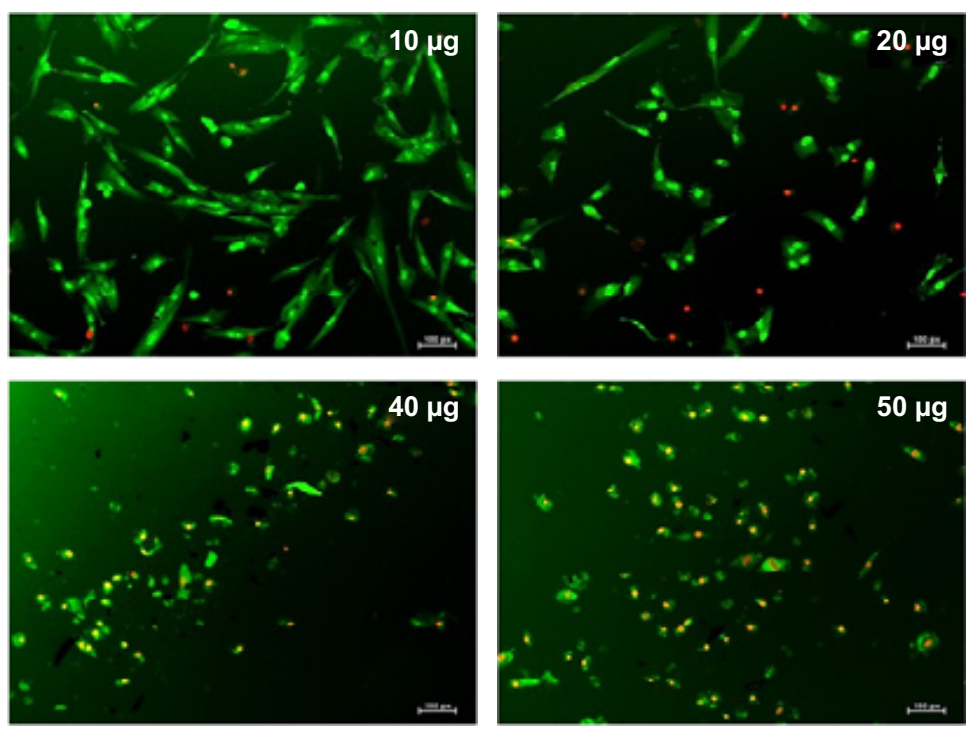

Note: (A) Scate bars= IO

Abbreviations: AgNPs, silver nanoparticles; hSSCs, human neonatal skin stromal cells. 


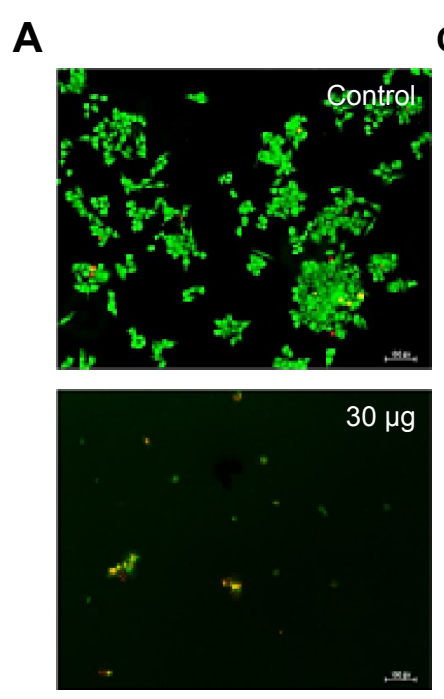

B

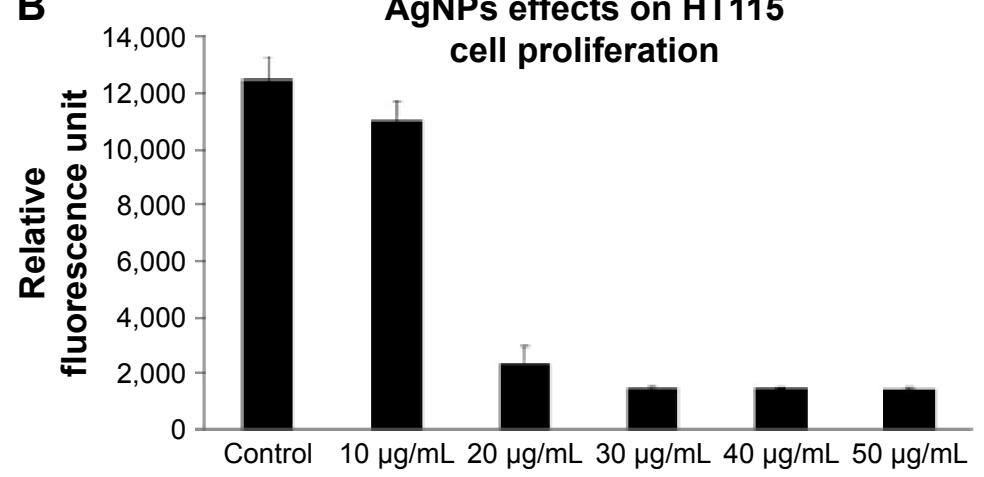

Cell viability assessment
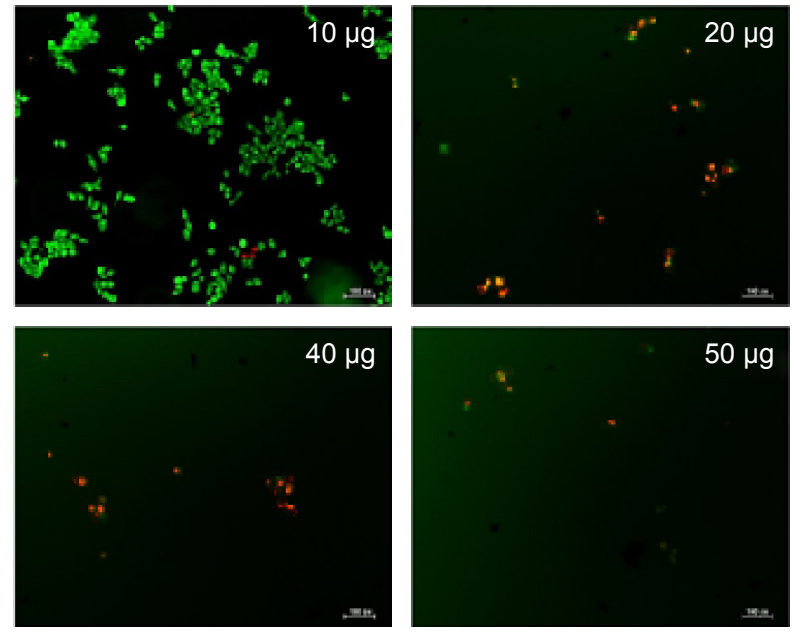

AgNPs effects on HT115

cell proliferation

Figure S2 (A) Cytotoxic effects of AgNPs (high dose) on HTI I5. (B) Alamar blue assay showing the proliferation.

Note: $(\mathbf{A})$ Scale bars $=10 \mu \mathrm{m}$.

Abbreviation: AgNPs, silver nanoparticles.

\section{Publish your work in this journal}

The International Journal of Nanomedicine is an international, peerreviewed journal focusing on the application of nanotechnology in diagnostics, therapeutics, and drug delivery systems throughou the biomedical field. This journal is indexed on PubMed Central, MedLine, CAS, SciSearch ${ }^{\circledR}$, Current Contents ${ }^{\circledR} /$ Clinical Medicine,
Journal Citation Reports/Science Edition, EMBase, Scopus and the Elsevier Bibliographic databases. The manuscript management system is completely online and includes a very quick and fair peer-review system, which is all easy to use. Visit http://www.dovepress.com/ testimonials.php to read real quotes from published authors. 